\title{
Histological Changes in the Lung and Liver of Mice Treated with Brake Pad Particles
}

\author{
Hajer Qais Ghaidan *
}

\author{
Nada Abdulrahman F. Al-Easawi
}

\author{
Received 3/9/2018, Accepted 24/12/2018, Published 2/6/2019
}

This work is licensed under a Creative Commons Attribution 4.0 International License.

\begin{abstract}
:
In the present study, the effects of brake pad particles of lung and liver histological sections were evaluated for (60) adult male mice. The animals were divided into three groups ( A,B,C) according to the periods of exposure $(4,8$, and 12$)$ weeks respectively exposed to brake pad particles in addition to the control groups (F) exposed to fresh air only. A special inhalation chamber designed locally has been used to expose the animals. The exposure to brake pad particles was $(2.228) \mu \mathrm{g} / \mathrm{m}^{3}$ for $30 \mathrm{~min} / \mathrm{day}, 5$ days/week for (4,8and12) weeks respectively.

The examination in group (A) of the histological sections of the lung showed the thickness of interalveolar septa. Also, a congestion of alveolar capillary was marked indicating pulmonary emphysema. The infiltration of alveolar macrophages showed the engulfed foreign particles (pad particles) within their cytoplasm, and peribronchial fibrosis. Group (B) showed the presence of pad particles (anthracosis), whereas the bronchial tree showed bronchitis with the bronchus-hyperplasia of mucin-producing cells (epithelial hyperplasia). Still another section showed an infiltration of mononuclear leukocytes and focal lobar necrosis. The third group (C), in turn, revealed acute interstitial bronchopneumonia with peribronchial focal necrosis and mild pulmonary edema with alveolar anthracosis.

As regards the liver, group (A) showed mild central venous congestion. Group (B), on the other hand, gave acute hepatitis, congestion of the central vein hyaline degeneration and mitotic figure having 2-3 nuclei. Severe congestion of the central vein with vascular amyloid deposition and most of the hepatocytes revealed coagulate necrosis in group (C). These changing tissues increased with increasing the exposure periods and were clearer in group $(\mathrm{C})$ which was exposed for 12 weeks.

The continuous exposure to brake pad particles lead to damaging important body organs tissues and effect on human health, these particles can be considered as a type of pollutants added to air pollutants in different cities of Iraq.
\end{abstract}

Key words: Brake pad particles, Heavy metals, Liver, Lung, Non-exhaust emission.

\section{Introduction:}

Air pollution is a major risk to health and to the environment, it's estimated to cause 1.3 million annual deaths worldwide (1). Traffic is the main source of several polluting elements that can be considered as developing contaminants. These elements are called traffic-related elements (TREs). Emissions due to road traffic are known to make a large influence on total particulate matter (PM) concentrations in urban areas and exposure to PM from vehicular emissions has been demonstrated to have harmful impacts on human health $(2,3)$. Nonexhaust emissions due to wear particles of vehicle parts such as brake, tire, clutch, and re-suspension of dust, researchers that a large part (about 50-85\% Department of Biology, College of Science, University of Baghdad, Baghdad, Iraq.

*Corresponding Author: Bahargeldi5@yahoo.com depending on the position) of the total traffic $\mathrm{PM}_{10}$ emissions are created from non-exhaust emissions (4).

The re-suspension of accumulated PM and road dust related particles are the primary contributors to non-exhaust emissions (5), $\mathrm{PM}_{10}$ emissions from disc brakes contribute up to (50\%) of the total non-exhaust emissions (6).

Both $\mathrm{PM}_{10}$ and $\mathrm{PM}_{2.5}$ can be inhaled into the lungs causing health effects. $\mathrm{PM}_{2.5}$ will penetrate deeper into the alveoli of the lungs than $\mathrm{PM}_{10}$. A previous study indicated the inhalation of metals content of brake pad particles such as $(\mathrm{Cu}, \mathrm{Cd}, \mathrm{Ni}$, $\mathrm{Pb}, \mathrm{Sb}, \mathrm{Zn}$ and $\mathrm{Fe}$ ) is associated with the following health effects: Cytokine production, cellular stress, radical generating metals toxicity which, in turn, leads to oxidative stress the high capacity to form reactive oxygen species (ROX) which may cause 
cell and tissues damaging events (7,8). Particulate matter can reduce lung function and cause lung diseases such as emphysema, bronchiectasis, pulmonary fibrosis, and cystic lungs. Long-term effects can also lead to lung cancer (9).

This study has established that it is very important to determine particles size (pad particles) to investigate the risk of deposition into the respiratory tract during inhalation, causing particles connected with posing hazards to oxidative stress and inflammation (10). Other researchers have shown that ultrafine particles may become bloodborne and translocate to other tissues such as the liver, kidneys, and brain (11).

The aims of the present work are to evaluate the effects of brake pads particles on mice lung and liver to determine whether or not pad particles can induce histological changes which could alter lung and liver functions.

\section{Materials and Methods:}

Sixty male mice (7-9) weeks age, weighing about (19-29) g were collected from inhalation exposure unit and divided into 4 groups, each group included 10 animals A (exposed for 4 weeks), B (exposed for 8 weeks), C (exposed for 12 weeks) and $\mathrm{F}$ were exposed to a fresh air.

The inhalation exposure unit, Fig.1, is a whole-body chamber which is locally made of glass with 56Lt. capacity. This chamber is classified as a dynamic system, and mostly used for a large number of laboratory animals for long-duration exposure studies $(12,13)$. The inhalation chamber is connected with Dust Generating Box (DGB) made of iron and used to generate break pad particles.

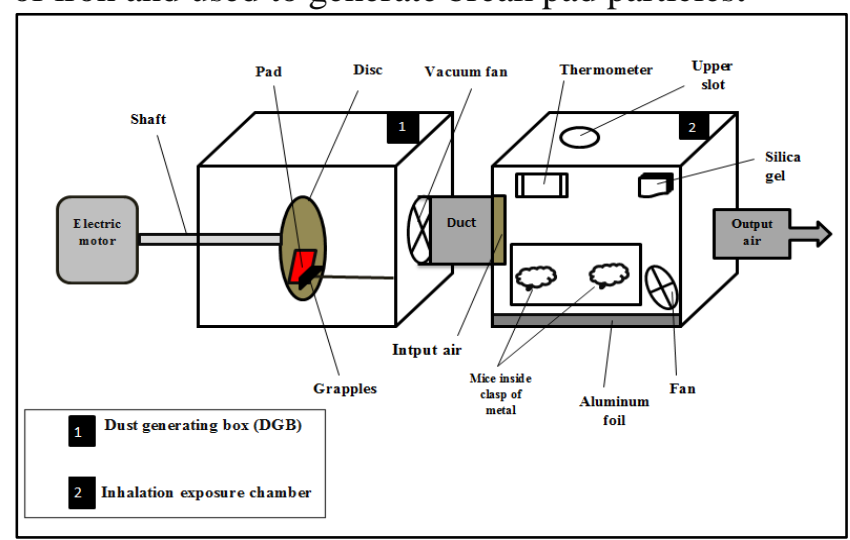

Figure 1. Inhalation chamber used in this study.

Groups of animals were exposed to concentration of (2.228) $\mu \mathrm{g} / \mathrm{m}^{3}$ brake pads particles according to the following regime: Group (A) were exposed for 4 weeks, Group (B) were exposed for 8 weeks and group (C) were exposed for 12 weeks, Table (1). The brake pad particles were generated inside (DGB) for 5 min daily, then each animal group was exposed to brake pad particles for 30 min/ day, 5 days/week for (4,8 and12) weeks respectively.

Inside (DGB), the rotary sharpening disc is connected with a shaft which is operated by electric motor, where another side in (DGB) is connected with a vacuum fan used for vacuuming dust (pad particles) through the duct to the inhalation chamber containing mice. Animals inside inhalation chamber group are placed in small cages and exposed for 30 minutes/day, while the group (F) control was exposed to fresh air only. This procedure was done during each exposure period, the inhalation chamber contained a fan and blower in order to continuously spread pad particles inside the chamber. The inhalation chamber was cleaned by alcohol 70\% and also cleaned (DGB) between each exposure period. The chamber was ventilated in the middle of exposure through a hole located at the top of the chamber to the prevention of oxygen deprivation for $5 \mathrm{~min}$ during the exposure time.

Animals were dissected after the end of the exposure period and the liver and lung were isolated and fixated with formalin $10 \%$ and then transferred to ethanol $70 \%$. After fixation, both lung and livers were processed, wax block and slides were prepared then stained with (H\&E) hematoxyline and eosin for microscopic examination (14).

\section{Results and Discussion: Grossly examination:}

Figure. $(2,3)$, shows gross samples for lung and liver belonging to animals exposed to fresh air (A) and exposed to brake pads particles (B) for 12 weeks in both.

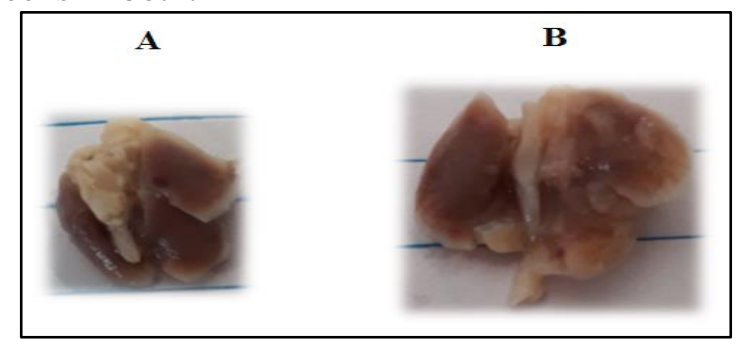

Figure 2. Show gross samples for lung: (A) Exposure to Fresh air, (B) Abnormalities lung exposure to Brake pads particles, 1x magnification power (MP).

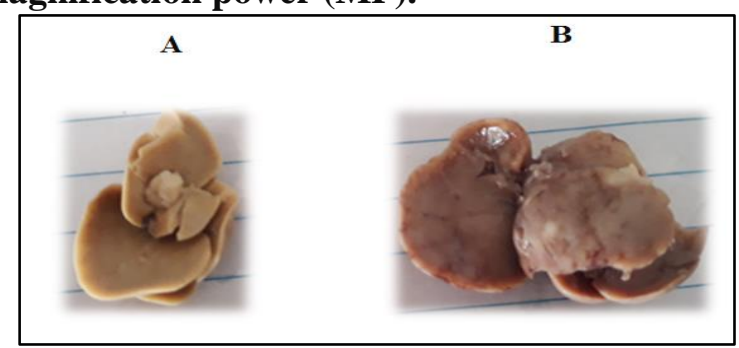

Figure 3. Show gross samples for liver: (A) Exposure to Fresh air, (B) Abnormalities liver exposure to Brake pads particles, 1x magnification power (MP). 
Histological examination:

Lung:

The examination of the histological lung sections belongs to control group showing normal tissue, Fig. (4).

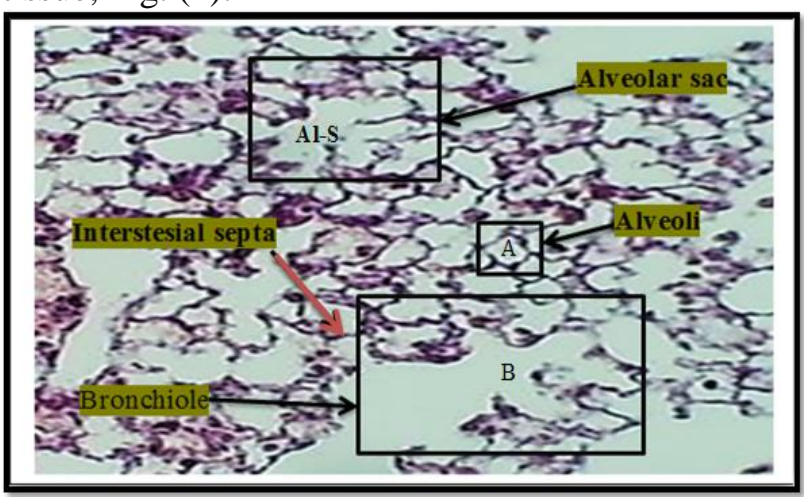

Figure 4. Section of the lung (control) shows: Alveolar sac (Al-S); Interstesial septa (red arrow); Alveoli (A) and Branchiole (B). H\&E stain, 40x magnification power (MP).
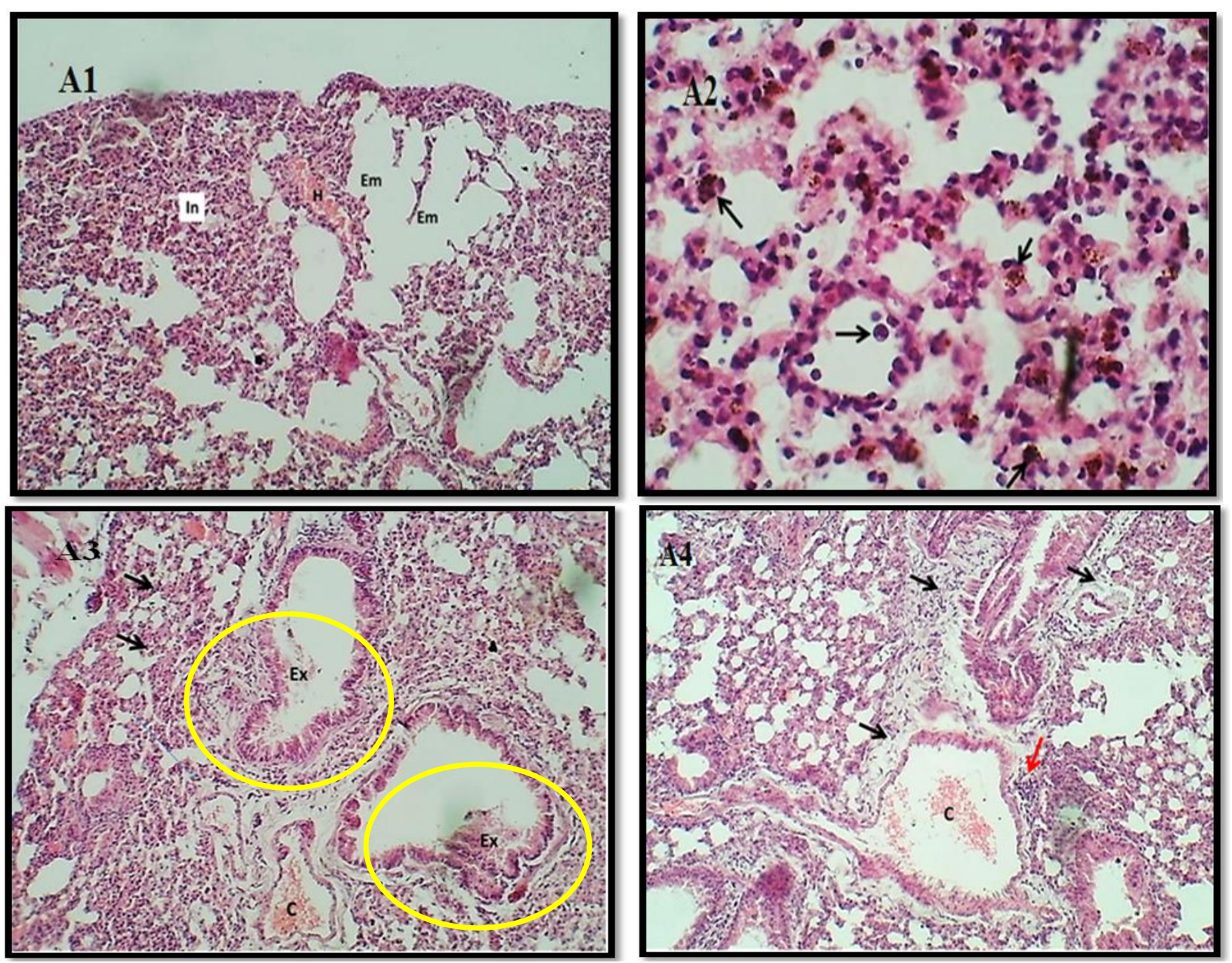

Figure 5. Sections of lung (group A) showed:(A1) interstitial pneumonia (In), emphysema (Em) and hemorrhage (H). H\&E stain, 20x MP;(A2) thickening of inter alveolar septa with marked increase in population of alveolar macrophages (Black arrows).H\&E stain, 40x MP;(A3) interstitial bronchopneumonia (arrows) with intra bronchial accumulation of inflammatory exudate (Ex) and hyperplasia (yellow circle). H\&E stain, 40x MP; and (A4) peribronchial fibrosis (Black arrows), congestion (C) and perivascular lymphocytic coughing (Red arrow).H\&E stain, 40x MP. 
The examination of the histological sections of the second group (B) exposed to brake pads particles for 8 weeks showed sever interstitial bronchopneumonia characterized by marked thickness of inter alveolar septa due to infiltration of mononuclear leukocytes and congestion of alveolar capillary associated with compressed alveolar collapse of the alveoli and presence of pad particles (anthracosis) and marked pulmonary emphysema. The bronchial tree showed bronchitis with the bronchushyperplasia of mucin-producing cells with hemorrhage and inflammatory infiltrate characterized per bronchial necrosis and infiltration of mononuclear leukocytes, other section showed focal lobar necrosis, Fig.(6 -B1,B2,B3,B4).
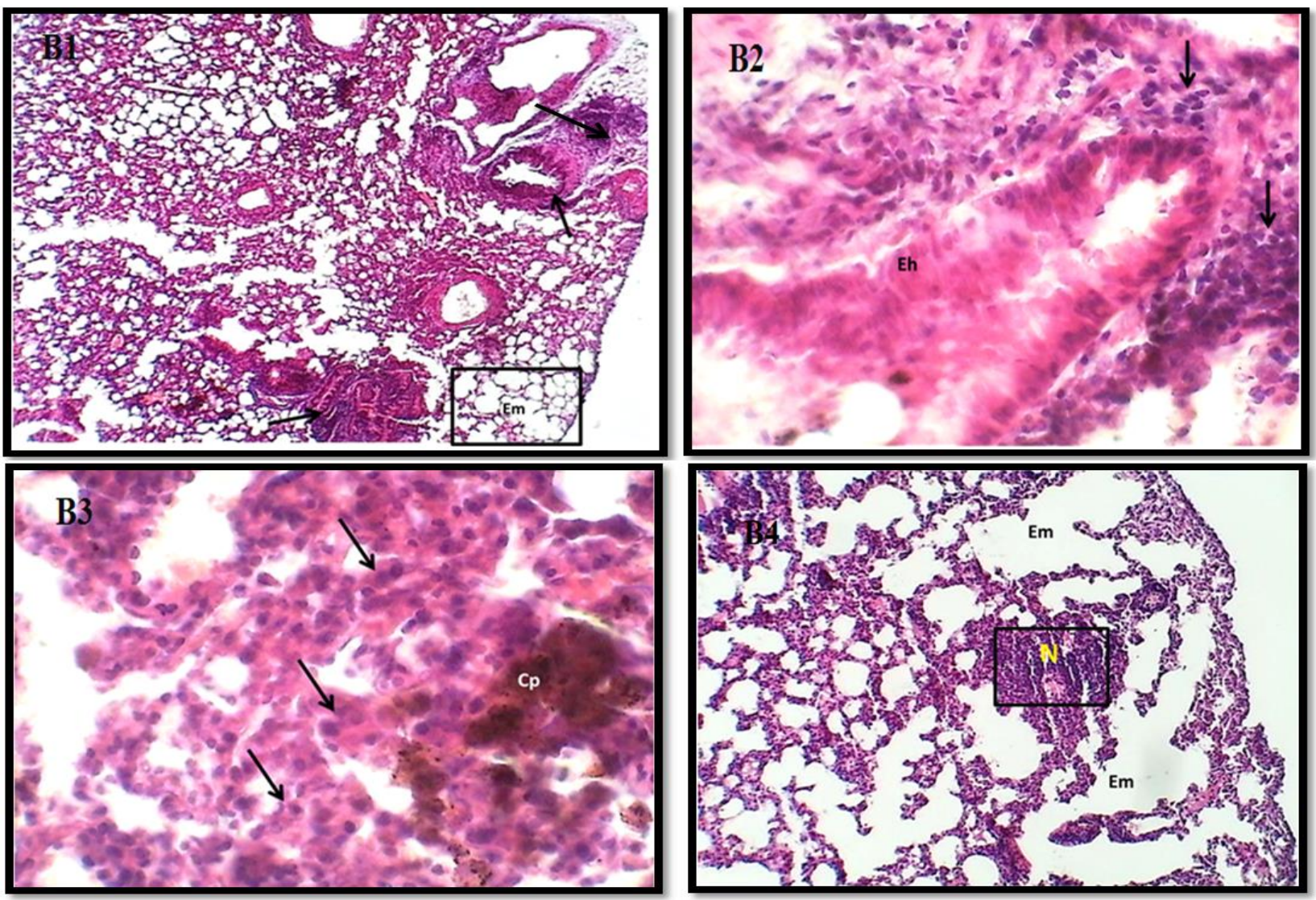

Figure 6. Sections of lung (group B) shows:(B1) sever bronchitis (Black arrows) with interstitial pneumonia and emphysema (Em). H\&E stain, 40x MP;(B2) bronchus epithelial hemorrhage (Eh) with peri bronchial lymphocytes infiltrates (Black arrows) . H\&E stain, 40x MP;(B3) alveolar collapse (Black arrows) with interstitial pneumonia and anathrocsis (intra alveolar pad particles) (Cp) . H\&E stain, 40x MP; and (B4) interstitial pneumonia with focal lobar necrosis (N) and emphysema (Em). H\&E stain, 40x MP.

The examination of the histological sections of the third group (C) exposed for 12 weeks showed similar changes found in group (B) and revealed marked acute interstitial bronchopneumonia with peribronchial focal necrosis Fig. (7- C1, C2 , C3). Other sections showed mild pulmonary edema with alveolar anthracosis characterized by marked deposited pad particles within alveolar wall associated with an increase in pulmonary macrophages,Fig.(7- C4).

Brake pad particles are an important source of traffic particles and therefore important to assess its potential toxic risk on human lung cells (15). The toxicity of $\mathrm{PM}_{2.5}$ transported by blood into different organs such as (lungs, livers, kidneys and brains) tissues of mammals, have significant effects on these activities and they have toxic effects attributed to oxidative damage or cause excess free radicals (16).

This finding agrees with the results of previous studies $(17,15)$. Their experiment was conducted on lung cells culture exposed to brake pad particles to investigate the cellular effect emitted particles on lung cell. The exposure to brake pad particles causes the formation of ROS for both braking behaviors (full stop and normal deceleration), increasing pro-inflammatory response in lung cells, and increasing interleukin-8 [is a chemokine produced by macrophages and other cell types such as epithelial cells, airway smooth muscle cells and endothelial cells (18). 
It has been mentioned in this study that the metals particles may lead to induction or aggravation of respiratory diseases. Lung epithelial cells were exposed to (Mn, V, Cr, $\mathrm{Zn}, \mathrm{Ni}$, and $\mathrm{Pb}$ ) at a concentration of $(0.5,5,50$, or 500$) \mu \mathrm{mol} / \mathrm{L}$ for 24 hours. The results indicate that various heavy metals have different effects on toxicity and proinflammatory responses of lung epithelial cells, those influences also depend on the oxidation states of the metals (19).

This study found out that the female Fischer rats exposed chronically inhalation to ultrafine particles of cadmium oxide. The lung of rats exposed to 550 $\mu \mathrm{g} / \mathrm{m}^{3}$ for $6 \mathrm{~h}$ for one day $(40 \mathrm{~nm}$ diameter of $\mathrm{Cd}$ particle). The histological changes of lung showed multifocal alveolar inflammation characterized by polymorphonuclear and mononuclear cell infiltration in the alveolar lumen. Cell debris was also observed. The alveolar septum was thickened by infiltration of inflammatory cell (20).

Another study mentioned that after inhalation of iron particulate matter (IPM) for 10 weeks, lung sections revealed that lung of the exposed mice gave abundant infiltration of macrophages and deposition of particulate matter (iron particles), deformed epithelium and degenerated cells, numbers of bi-nucleate cells (BNC) and multinucleate cells (MNC) in lung cell and these effects are seen as a biomarker of the inflammation (21).
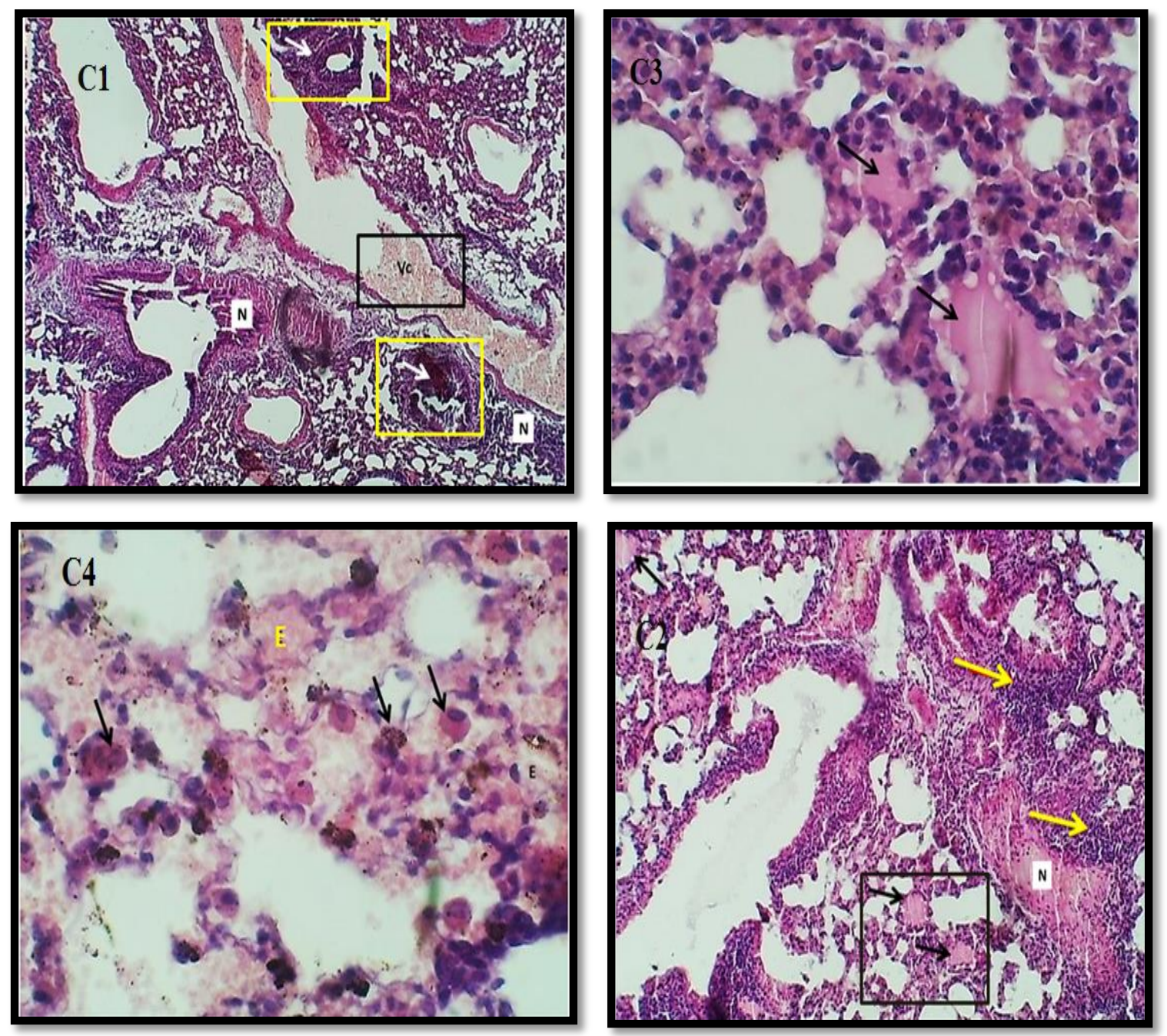

Figure (7): Sections of lung (group C) shows:(C1) vascular congestion (Vc) with interstitial pneumonia, per bronchial necrosis (N) and bronchitis (White arrows). H\&E stain, 40x MP; (C2) interstitial pneumonia and per bronchial necrosis $(\mathbf{N})$, bronchitis (Yellow arrows) and pulmonary edema (black arrows) . H\&E stain, 40x MP;(C3) alveolar edema (Arrows). H\&E stain, 40x MP; and (C4) alveolar edema (E) and intra alveolar pad particles deposit and alveolar macrophages showed intra cytoplasmic carbon particles (arrows). H\&E stain, 40x MP.

\section{Liver:}

Fig.8 (A1) shows control section of liver exposed to fresh air only. Group (A) showed only mild central venous congestion, Fig. (8- A2). 

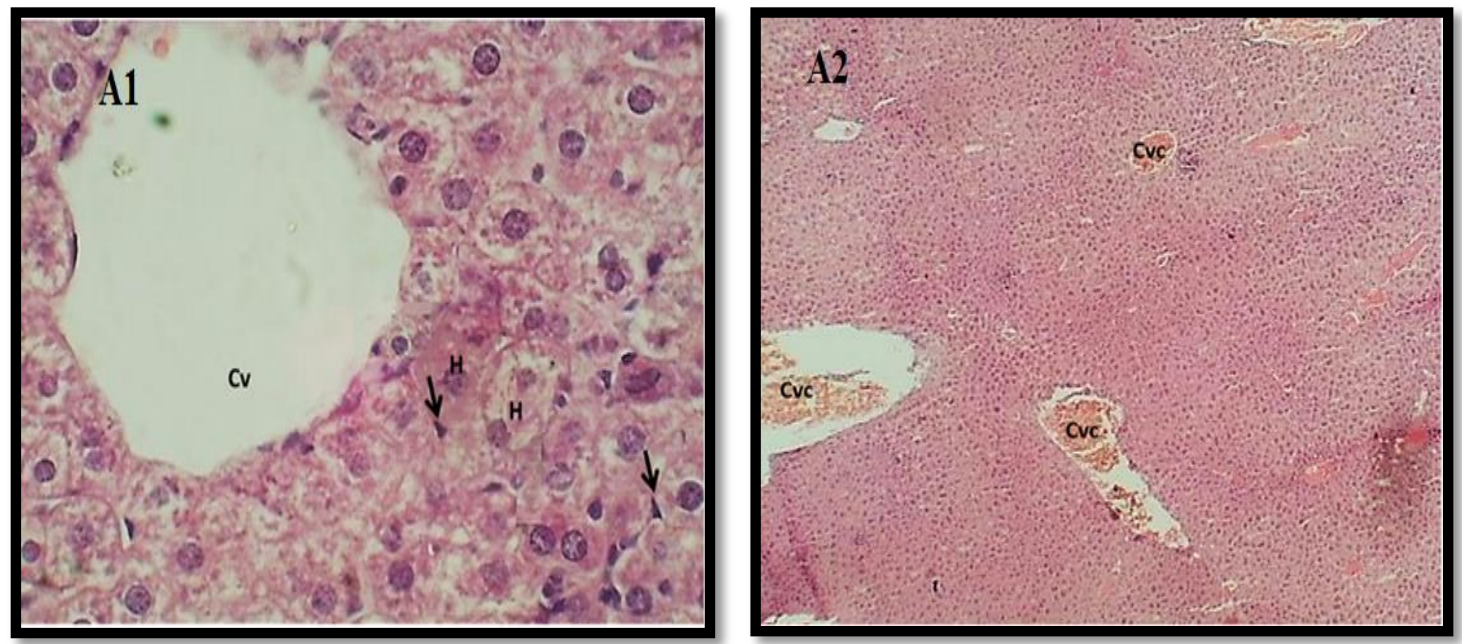

Figure 8. Sections of liver lobule (control) shows:(A1) normal central vein $(\mathrm{Cv})$, hepatocytes $(\mathrm{H})$ and kupffer cells (arrows). H\&E stain 40x MP; (A2) congestion and distension of central veins (Cvc). H\&E stain, 20x MP.

Group (B) was exposed for 8 weeks, the sections of liver showed congestion of the central vein characterized by multi focal hepatic necrosis infiltrated with mononuclear leukocytes with hyper cellularity of kupffer cells. Some hepatocytes showed the presence of hyaline degeneration and other showed mitotic figure having 2-3 nuclei, Fig. (9- B1, B2, B3).
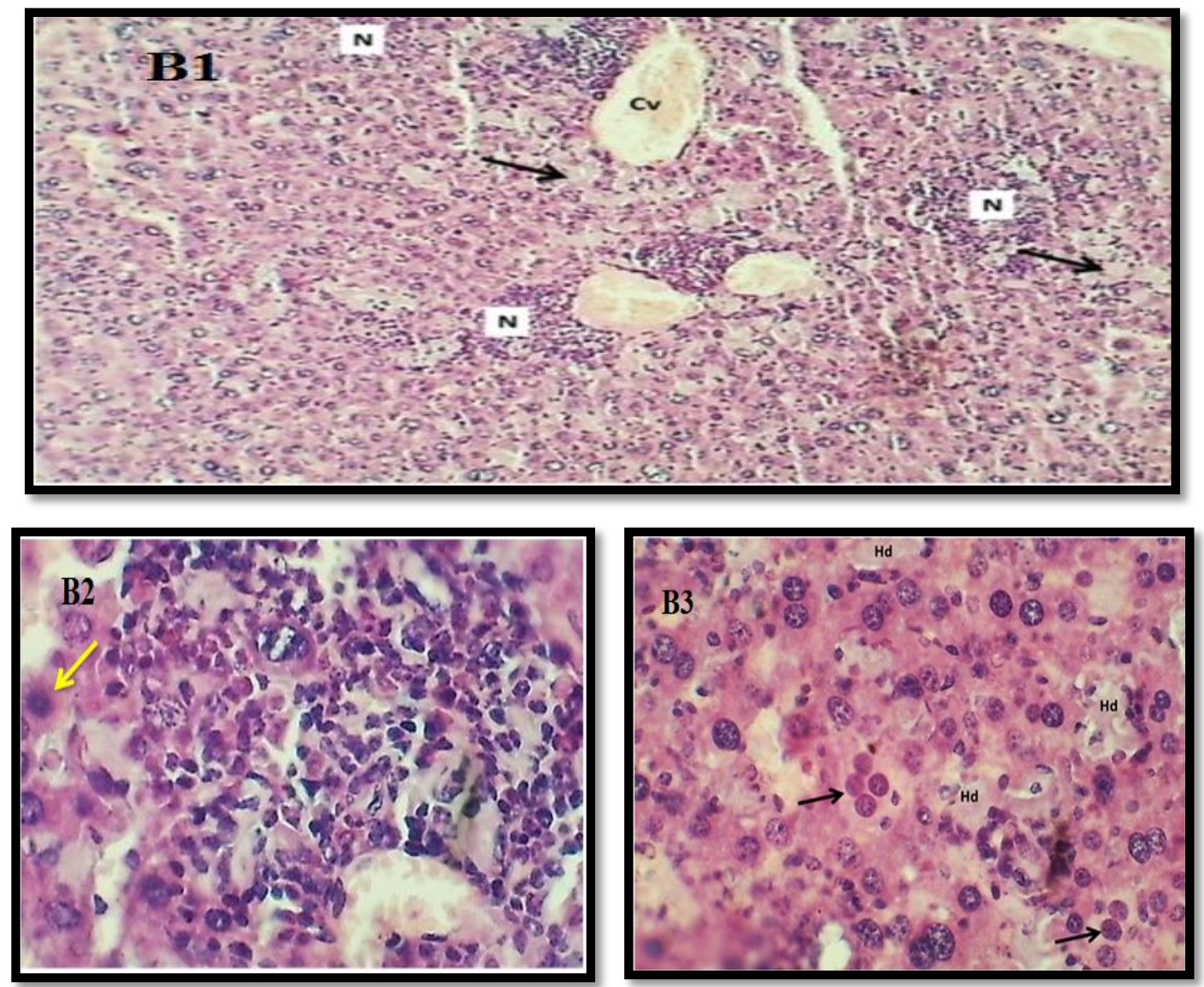

Figure 9. Sections of liver (group B) showed:(B1) multifocal infiltration (N), congestion of central vein with amyloid deposition (Cv) and hyaline degeneration (Black arrows). H\&E stain, 20x MP;(B2) infiltration of mononuclear leukocytes within area of necrotic hepatocytes, Normal cell (yellow arrow). H\&E stain, 40x MP; and (B3) Hyaline degeneration of hepatocytes (Hd) and multinuclear hepatocytes (Arrows).H\&E stain, 40x MP. 
Group (C) which was exposed for 12 weeks, showed sever congestion of the central vein with vascular amyloid deposition. The liver parenchyma showed disarranged hepatocytes cords within hepatic lobule, multiple focal hyaline degeneration, perivascular hyaline degeneration and most of hepatocytes revealed marked coagulate necrosis, Fig. (10- C1, C2, C3).
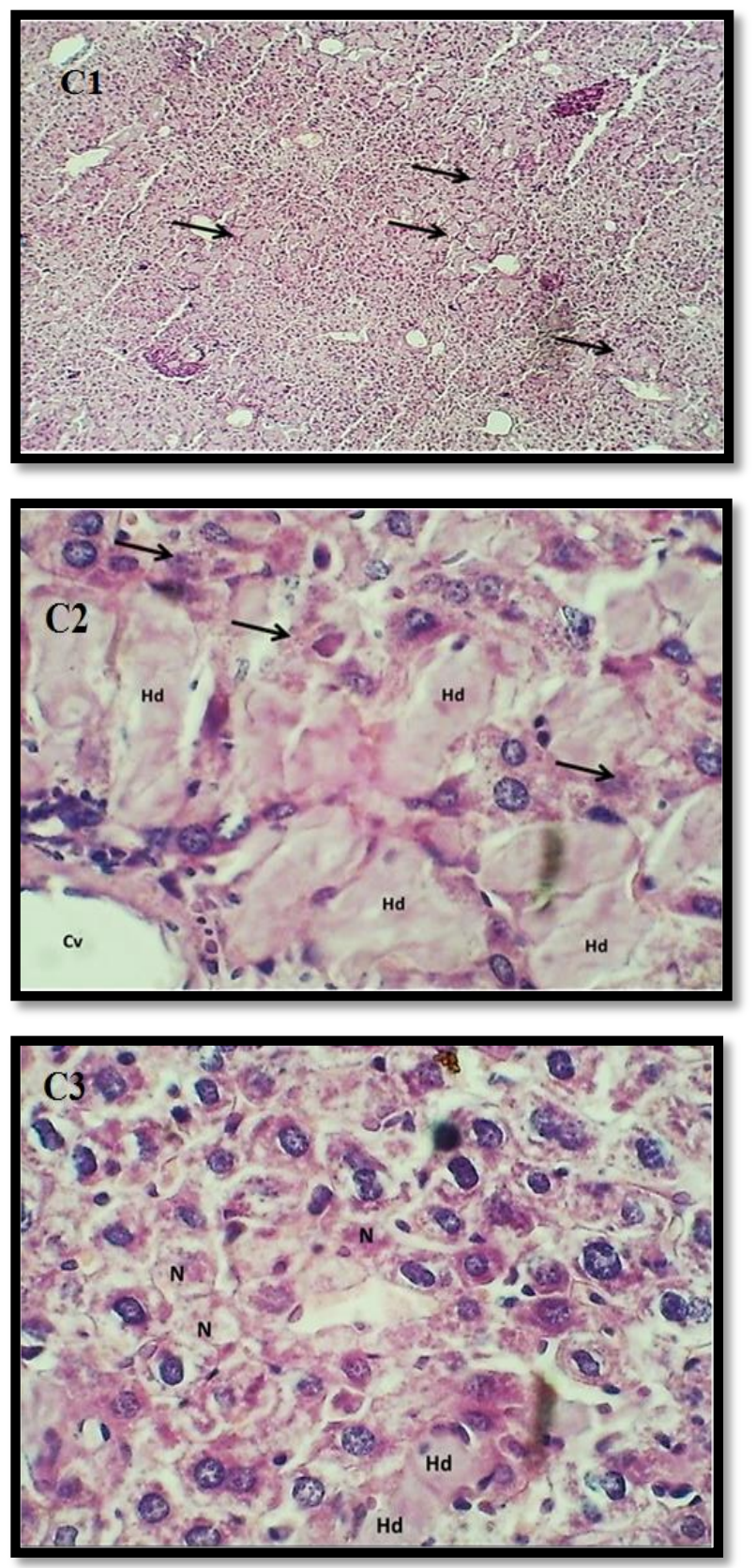

Figure (10): Sections of liver (group C) showed:(C1) multiple focal hyaline degeneration (Black arrows) . H\&E stain, 20x MP;(C2) central vein $(\mathrm{Cv})$, perivascular hyaline degeneration (Hd) and necrotic hepatocytes (Black arrows).H\&E stain, 40x MP; and (C3) disarranged architecture of cords of hepatocytes with hyaline degeneration (Hd) and necrosis with karylosis (N). H\&E stain, 40x MP.
This finding accords with the results of study which mentioned that copper powder is widely used in brake linings/pads where it functions as a heat conductor since it dissipates the heat of friction. Nasal inhaled copper particles effect on the liver when increasing significantly with the group exposed to $40 \mathrm{mg} / \mathrm{kg}$ compared to the control group (22).

This study mentioned that liver cells (hepatocytes) in mice exposure under certain doses from zinc $(\mathrm{Zn})$, the animals received to zinc through tap water. The experimental design consisted with four groups (1 control,2,3,4). The groups $(3,4)$ of animals which received high dose $(10 \mathrm{mg} / \mathrm{kg}$ and 15 $\mathrm{mg} / \mathrm{kg}$ ) body weight consecutively, the results showed various degrees of degenerative changes in the hepatocytes, such as the dark appearance of the cytoplasm, the increased size and the presence of spaces, whereas none of these changes was present in group (2) that received a low dose $(5 \mathrm{mg} / \mathrm{kg})$ body weight from $\mathrm{Zn}$ consecutively (23).

While another study investigated the effect of fly ash inhalation (4 h daily, 5 days a week) for 28 days on the deposition of metal ions and effects histopathological changes in the liver. The results showed an increase in the concentration of heavy metals such as $(\mathrm{Cd}, \mathrm{Cr}, \mathrm{Cu}, \mathrm{Mn}$, and $\mathrm{Pb})$ in the tissues of exposed rats thickened portal vein, hepatocytes necrotic changes, kupffer cells were hypertrophied and infiltration of foreign particles (fly ash from heavy metals) in coarse form was observed within the hepatocytes (24).

In this study, the examination of histological section experimental group of mice given a subcutaneous injection of cadmium at a dose of $(4 \mathrm{mg} / \mathrm{Kg})$ showed more abundant histological changes in the hepatocytes the presence of spaces, dense appearance of the cytoplasm and increased size and tubular-shaped hepatocytes. Another group of mice given a subcutaneous injection of cadmium at a dose of $(2 \mathrm{mg} / \mathrm{Kg})$ showed abundant histological changes in the hepatocytes such as the presence of spaces, increased in size, and dense appearance of the cytoplasm this result agrees with (25).

Another study revealed the toxic effects of heavy metals such as nickel and chrome on the liver and kidney structures of mature male mice weighing 20-30 g, (10-13 weeks old), which were treated orally with different doses $(20,40$ and 60 $\mathrm{mg} / \mathrm{kg}$ of $\mathrm{NiCl} 2$ and 20,60 and $100 \mathrm{mg} / \mathrm{kg}$ of $\mathrm{K} 2 \mathrm{Cr} 2 \mathrm{O} 7)$. The histopathological changes were found in both liver and kidney included degeneration of cell, cellular swelling, necrosis, and congestion of blood vessels (26).

The cause of metallic elements or toxicant stimulates liver injury caused by involvement of 
toxicant metabolites might cause depletion of reduced glutathione, a range of chemical reaction including covalent binding and oxidative stress with the resultant effect on protein. It may have a direct effect on the chemicals in organelles like endoplasmic reticulum cytoskeleton, mitochondria, and nucleus or may affect indirectly the inhibition or activation of gene expression leading to cell death either through shrinking or apoptotic process or necrosis $(27,28)$. The congestion caused by toxicant metallic elements producing pathological changes might result in an impaired liver performance that interferes with the secretion of plasma proteins.This leads to decreasing blood osmotic pressure with, therefore, decreasing drainage of tissue $(29,30)$. These studies observed that attributable infiltration in the hepatic tissue increased the permeability of blood vessels that occurs when the contraction of the endothelial cells of blood vessels responds to certain chemicals or as a result of the loss of particles desmosomes, which lies between the endothelial cells, that permits the passage of blood vessels $(31,32)$. Other studies observed that the rush of inflammatory cells from the center to the periphery endothelial line the blood off to find its way out of the vessel, these changes lead the blood vessels to expand $(33,34)$.

The conclusion of the present study provides evidence concerning the toxic and harmful effects of brake pad particles in the lung and liver of mice after inhalation. Therefore, break pad particle is considered as an important non-exhaust air pollutant.

\section{Conflicts of Interest: None.}

\section{References:}

1. Pope III CA, Turner MC, Burnett RT, Jerrett M, Gapstur SM, Diver WR, et al. Relationships between fine particulate air pollution, cardiometabolic disorders, and cardiovascular mortality. J Circ Res. 2015 Jan; 116(1):108-115.

2. Amato F, Cassee FR, Van der Gon HAD, Gehrig R, Gustafsson M, Hafner W, et al. Urban air quality: the challenge of traffic non-exhaust emissions. J hazard Mater. 2014 Apr; 275:31-36.

3. Amato F, Favez O, Pandolfi M, Alastuey A, Querol X, Moukhtar S, et al. Traffic induced particle resuspension in Paris: Emission factors and source contributions. J Atmos. Environ. 2016 Mar;129:114124.

4. Gonzalez RO, Strekopytov S, Amato F, Querol X, Reche C, Weiss D. New insights from zinc and copper isotopic compositions into the sources of atmospheric particulate matter from two major European cities. J Environ Sci Tech. 2016 Aug;50(18):9816-9824.

5. Amato F, Karanasiou A, Cordoba P, Alastuey A, Moreno T, Lucarelli F, et al. Effects of road dust suppressants on PM levels in a Mediterranean urban area. J Environ Sci Tech. 2014 Jun;48(14):80698077.

6. Heal MR, Hammonds MD. Insights into the composition and sources of rural, urban and roadside carbonaceous PM10. J Environ Sci Tech. 2014 Jul;48(16):8995-9003.

7. Ciudin R, Verma PC, Gialanella S, Straffelini G. Wear debris materials from brake systems: environmental and health issues. J WIT Trans Ecol Envir. 2014;191(12):1423-1434.

8. Shirmohammadi F, Lovett C, Sowlat MH, Mousavi A, Verma V, Shafer MM, et al. Chemical composition and redox activity of $\mathrm{PM}_{0 .} 25$ near Los Angeles International Airport and comparisons to an urban traffic site. J Sci Total Environ. 2018 Jan;610611(1):1336-1346.

9. Patton AP, Calderon L, Xiong Y, Wang Z, Senick J, Sorensen Allacci M, et al. Airborne particulate matter in two multi-family green buildings: Concentrations and effect of ventilation and occupant behavior. J Int Environ Res Public Health. 2016 Nov;13(1):144.

10. Sharma A, Singh S, Kulshrestha UC. Determination of Urban Dust Signatures through Chemical and Mineralogical Characterization of Atmospheric Dustfall in East Delhi (India). J Ind Geophys Union. 2017 Mar;21(2):140-147.

11. Wardoyo AY, Juswono UP, Noor JA. An observation of histological evidence on internal organ damages in mice caused by repeated exposures to motorcycle emissions. J AIP Conf Proc. 2017 May; 1844(1):020007.

12. Iijima A, Sato K, Yano K, Kato M, Kozawa K, Furuta N. Emission factor for antimony in brake abrasion dust as one of the major atmospheric antimony sources. J Environ Sci Technol. 2008 Dec;42(8):2937-2942.

13. Kukutschova J, Moravec P, Tomasek V, Matejka V, Smolik J, Schwarz J, et al. On airborne nano/microsized wear particles released from low-metallic automotive brakes.J Environ Pollut. 2011 Nov;15(4):998-1006.

14. Bancroft JD, Gamble M. Theory of practice and histological techniques.6th ed. Philadelphia:Churchill Livingstone; 2008. 725 p.

15. Gasser M, Riediker M, Mueller L, Perrenoud A, Blank F, Gehr P, et al. Toxic effects of brake wear particles on epithelial lung cells in vitro. J Part Fibre Toxicol. 2009 Nov;6(1):30.

16. Chen R, Hu B, Liu Y, Xu J, Yang G, Xu D, et al. Beyond PM2. 5: the role of ultrafine particles on adverse health effects of air pollution. J Biochim Biophys Acta Gen Subj. 2016 Mar;1860(12):28442855.

17. Riediker M, Gasser M, Perrenoud A, Gehr P, Rothen - Rutishauser BA. System to test the toxicity of brake wear particle. Am J Respir Crit Care Med. 2008 Jun;177(1):1-23.

18. Hedges JC, Singer CA, Gerthoffer WT. Mitogenactivated protein kinases regulate cytokine gene expression in human airway myocytes. Am J Respir Cell Mol Biol. 2000 Jan;23(1):86-94. 
19. Honda A, Tsuji K, Matsuda Y, Hayashi T, Fukushima W, Sawahara T, et al. Effects of air pollution-related heavy metals on the viability and inflammatory responses of human airway epithelial cells. Int J Toxicol. 2015 Apr;34(2):195-203.

20. Takenaka S, Karg E, Kreyling WG, Lentner B, Schulz H, Ziesenis A, et al. Fate and toxic effects of inhaled ultrafine cadmium oxide particles in the rat lung. J Inhal Toxicol. 2004 Oct;16(1):83-92.

21. Qazi JI, Nasreen Z, Nazir S. Effects of inhalation of iron emission particles on some lung cellular parameters in mice. J Pak Zool. 2009 Jan;41(2):149153.

22. Liu Y, Gao Y, Zhang L, Wang T, Wang J, Jiao F, et al. Potential health impact on mice after nasal instillation of nano-sized copper particles and their translocation in Mice. J Nanosci Nanotechnol. 2009 Dec;9(6):1-9.

23. Albir AA. Light Microscopic Study of the Effect of Zinc on Liver in Mice. J IPM. 2007 Jan;6(2):157-163.

24. Mania U, Prasada AK, Kumarb VS, Lal K, Kanojiac RK, Chaudharid BP, et al. Effect of fly ash inhalation on biochemical and histomorphological changes in rat liver. J Ecotoxicol Environ Saf. 2007 Dec; 68(1):126133.

25. Albir AA. Histological Changes in the Liver of Mice Treated with Cadmium. IJS. 2013 Jan; 54(1):50-54.

26. Kehiosh HJ, Al-fatlawi AC. Histopathological changes of heavy metals Nickel Chloride (II) and Potassium dichromate (VI) on the Liver and Kidney of Swiss Male Mice. Ker J Pharm Sci. 2017 Mar;13(1):221-230.
27. Kaplowitz N. Biochemical and cellular mechanisms of toxic liver injury. J Semin Liver Dis. 2002 May; 22(2):137-44.

28. Kurutas EB. The importance of antioxidants which play the role in cellular response against oxidative/nitrosative stress: current state. J Nutrition. $2015 \mathrm{Jul} ; 15(1): 71$.

29. Lacroix I, Lapeyre-Mestre M, Bagheri H, Pathak A, Montastruc JL. Nonsteroidal antiinflammatory druginduced liver injury: a casecontrol study in primary care. J Fundam Clin Pharmacol.2004 Apr; 18(2): 201-206.

30. Syed M, Skonberg C, Hansen SH. Inhibition of ATP synthesis by fenbufen and its conjugated metabolites in rat liver mitochondria. J Toxicol In Vitro. 2016 Mar; 31(1):23-29.

31. Cotran RS, Kumar V, Colline T. Morphological features of a poptosis in: Robin pathology basis of Disease. Ch.1,6th edn., W.B Saunders co.; 1999.1-30 p.

32. Reglero-Real N, Garcia-Weber D, Millan J. Cellular barriers after extravasation: leukocyte interactions with polarized epithelia in the inflamed tissue. J Mediators Inflamm. 2016 Jan; 2016 (1): 10.

33. Kumar V, Abbas AK, Fausto N, Mitchell RN. Robbins Basic Pathology. 8th ed. Saunders Elsevier; 2007. 632-634 p.

34. Melchiorri AJ, Bracaglia LG, Kimerer LK, Hibino N, Fisher JP. In vitro endothelialization of biodegradable vascular grafts via endothelial progenitor cell seeding and maturation in a tubular perfusion system bioreactor. J Tissue Eng Part C: Methods. 2016 Jul; 22(7):663-670.

\title{
التغيرات النسجية في رئة وكبد الفئران المعاملة مع جزيئات وسائد مكابح السيارات ندى عبد الرحمن فليح العيساوي
}

\author{
هاجر قيس غيدان \\ قسم علوم الحياة، كلية العلوم، جامعة بغداد، بغداد، العراق.
}

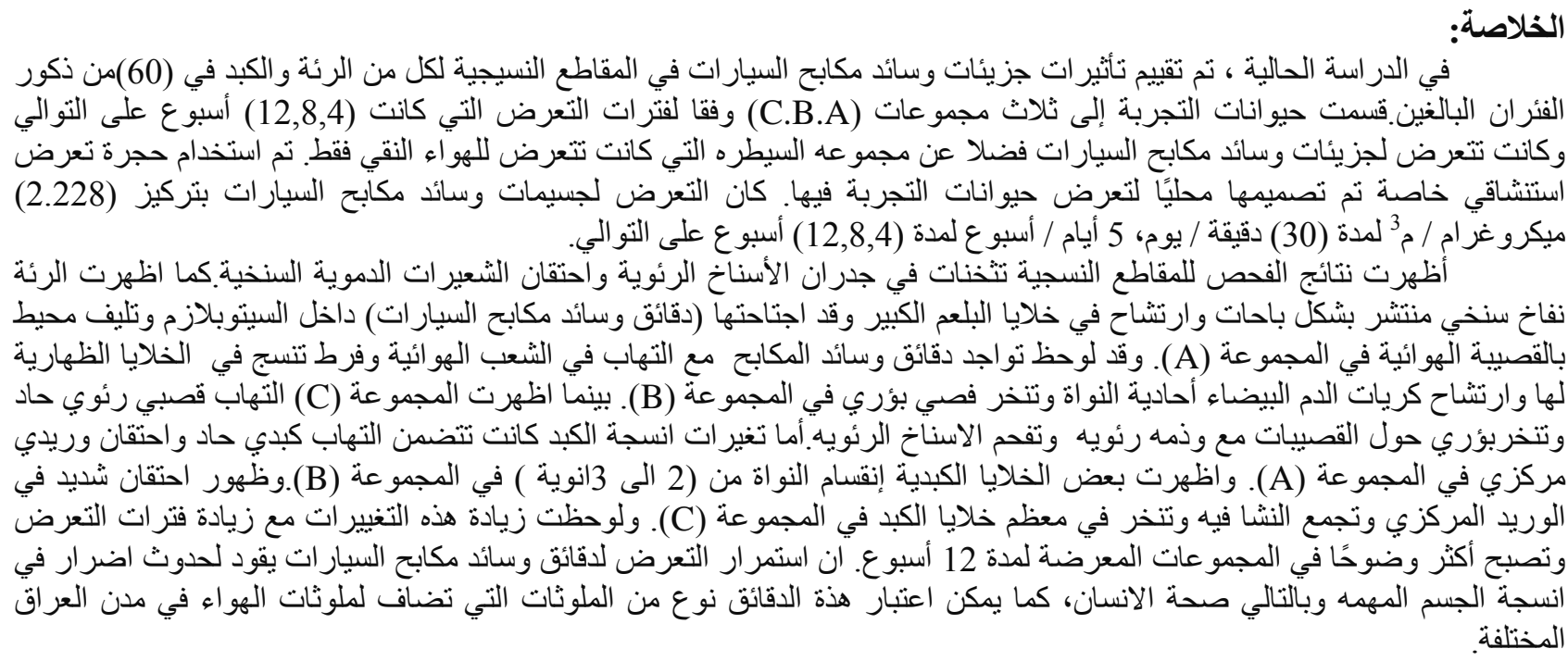

الكلمات المفتاحية: جزيئات وسائد مكابح السبارة، المعادن الثقبلة، الكبد، الرئة، الأنبعاثات غير العادم. 